\title{
CORRIGENDUM
}

\section{Helminths of red foxes (Vulpes vulpes) and raccoon dogs (Nyctereutes procyonoides) in Lithuania-CORRIGENDUM}

RASA BRUŽINSKAITÉ-SCHMIDHALTER, MINDAUGAS ŠARKŪNAS, ALVYDAS MALAKAUSKAS, ALEXANDER MATHIS, PAUL R. TORGERSON and PETER DEPLAZES

doi: 10.1017/S0031182011001715, Published by Cambridge University Press, January 2012, Vol. 139(1).

In Table 2, the missing data under column k for Capillaria plica should be inserted as $0 \cdot 22(0 \cdot 18-0 \cdot 30)$.

In Table 3, the missing data under column k for Toxocara canis should be inserted as $0 \cdot 061(0 \cdot 024-0 \cdot 143)$.

REFERENCE

Bružinskaitè-Schmidhalter, R. et al. (2012). Helminths of red foxes (Vulpes vulpes) and raccoon dogs (Nyctereutes procyonoides) in Lithuania. Parasitology 139, 120-127. 